Latinović, N., Jaćimović, Ž., Latinović, J., Kosović, M., Vlahović, M., (2021): Study on fungicidal activity of newly synthesized complex compounds of $\mathrm{Cu}$ (II), Zn (II) and Ni (II) with pyrazole-derived ligands against the phytopathogenic fungus Phomopsis viticola Sacc. In laboratory conditions. Agriculture and Forestry, 67 (1): $27-33$

DOI: 10.17707/AgricultForest.67.1.02

\author{
Nedeljko LATINOVIĆl, Željko JAĆIMOVIĆ \\ Milica KOSOVIĆ ${ }^{2}$ Mia VLAHOVIĆ
}

\title{
STUDY ON FUNGICIDAL ACTIVITY OF NEWLY SYNTHESIZED COMPLEX COMPOUNDS OF Cu (II), Zn (II) AND Ni (II) WITH PYRAZOLE-DERIVED LIGANDS AGAINST THE PHYTOPATHOGENIC FUNGUS Phomopsis viticola Sacc. IN LABORATORY CONDITIONS
}

\section{SUMMARY}

In the continuation of our detailed studies on pyrazole and its derivatives, $\mathrm{Cu}$ (II), Zn (II) and Ni (II) complexes were synthesized with ligand 4-Bromo-2(1H-pyrazol-3-yl) phenol (HL) and their potential fungicidal activity against the phytopathogenic fungus Phomopsis viticola Sacc. (causal agent of Phomopsis cane and leaf spot disease of grapevine) was tested. Based on elemental (C, H, N) analysis and conductometric measurements, the formulas of complex compounds were determined. Biological research based on determining the inhibitory effects of commercial fungicide with active substances pyraclostrobin and metiram, ligand, and all newly synthetized complexes on Ph. viticola has been carried out.

Keywords: 4-Bromo-2-(1H-pyrazol-3-yl) phenol; complexes of $\mathrm{Zn}, \mathrm{Ni}$ and $\mathrm{Cu}$; Phomopsis viticola; active fungicidal substances, Phomopsis cane and leaf spot disease of grapevine

\section{INTRODUCTION}

Grapevine production is very important for Montenegrin agriculture. Vineyards cover an area of 2783.2 ha (MONSTAT, 2017). Cultivation of grapevine is endangered by numerous diseases, and one of the most significant is Phomopsis cane and leaf spot caused by the phytopathogenic fungus Phomopsis viticola Sacc. (Latinovic and Latinovic, 2011). The disease occurs every year and makes more or less damages depending on the intensity of the disease, while in exceptional cases it can lead to vine declining. In conditions of Montenegro, the symptoms usually occur on canes and leaves (Latinovic, 2007), while in the

\footnotetext{
${ }^{1}$ Nedeljko Latinović (corresponding author: nlatin@ucg.ac.me), Jelena Latinović, University of Montenegro, Biotechnical Faculty, Mihaila Lalića 15, Podgorica, MONTENEGRO

${ }^{2}$ Željko Jaćimović, Milica Kosović, Mia Vlahović, University of Montenegro, Faculty of Metallurgy and Technology, Cetinjski put bb, Podgorica, MONTENEGRO

Notes: The authors declare that they have no conflicts of interest. Authorship Form signed online. 
world they can also appear on berries (Pscheidt and Pearson, 1989). According to Latinovic et al. (2003), particular problem is the fact that the most widespread varieties in Montenegrin vineyards Vranac and Kratosija are very susceptible to this disease. To control the disease, preventive measures are used that enable better aeration of the plant canopy and removal of infected plant parts, however treatments with fungicides are still essential. For this purpose, fungicides from the chemical groups' dithiocarbamates and strobilurins are the most commonly used (Latinovic, 2007; Gubler et al., 2015).

Pyrazole-based compounds and their transition metal complexes have attracted considerable research interest because of their potentially beneficial biological properties. The wide biological activity of this class of compounds (anticancer, antimicrobial, antiviral, anti-inflammatory, antifungal and others) is described in several reviews (Alex and Kumar, 2014; Kumar et al., 2013; Chimenti et al., 2006; Trofimenko, 1986). These results represent a part of our continued work with pyrazole-based complex (Jaćimović et al., 2013; Jaćimović et al., 2017a; Jaćimović et al., 2017b). In agriculture, they are in the use as pesticides (Lemaire et al., 2006; Vicentini et al., 2004; Singh et al., 2000).

In this paper, the syntheses of tree new $\mathrm{Cu}$ (II) complexes, $\mathrm{Zn}$ (II) and $\mathrm{Ni}(\mathrm{II})$ compounds of formulas $\mathrm{Cu}(\mathrm{L}-\mathrm{H})_{2},\left[\mathrm{Cu}(\mathrm{L}-\mathrm{H})_{2}\right] \mathrm{Cl}_{2},\left[\mathrm{Cu}(\mathrm{L}-\mathrm{H})_{2}\right]\left(\mathrm{NO}_{3}\right)_{2}, \mathrm{Zn}(\mathrm{L}-\mathrm{H})_{2}$ and $\mathrm{Ni}(\mathrm{L}-\mathrm{H})_{2} \cdot 4 \mathrm{H}_{2} \mathrm{O}$ obtained in reaction of $\mathrm{Cu}(\mathrm{OAc})_{2}, \mathrm{CuCl}_{2}, \mathrm{Cu}\left(\mathrm{NO}_{3}\right)_{2}$, $\mathrm{Zn}(\mathrm{OAc})_{2}$ and $\mathrm{Ni}(\mathrm{OAc})_{2}$ with 4-Bromo-2-(1H-pyrazol-3-yl)phenol (HL) is described. Their activity was examined to the mycelial growth of Ph. viticola in vitro. Obtained results were compared with the commercial fungicide whose one active substance is pyraclostobin that belongs to pyrazole derivates.

\section{MATERIAL AND METHODS \\ Preparation of complexes}

Microcrystals of the complex of formula $\mathrm{Cu}(\mathrm{L}-\mathrm{H})_{2}$ were obtained by mild heating in the reaction on warm methanolic solutions of $\mathrm{Cu}(\mathrm{OAc})_{2} \cdot \mathrm{H}_{2} \mathrm{O}$ and ligand 4-Bromo-2-(1H-pyrazol-3-yl)phenol in molar ratio 1:2. The formed microcrystals were filtered after $24 \mathrm{~h}$ and washed with methanol.

Microcrystals of the complex of formula $\left[\mathrm{Cu}(\mathrm{L}-\mathrm{H})_{2}\right]\left(\mathrm{NO}_{3}\right)_{2}$ were obtained by mild heating in the reaction on warm methanolic solutions of $\mathrm{Cu}\left(\mathrm{NO}_{3}\right)_{2} \cdot 3 \mathrm{H}_{2} \mathrm{O}$ and ligand 4-Bromo-2-(1H-pyrazol-3-yl)phenol in molar ratio 1:2. After two days, the formed microcrystals were filtered and washed with methanol.

Microcrystals of the complex of formula $\left[\mathrm{Cu}(\mathrm{L}-\mathrm{H})_{2}\right] \mathrm{Cl}_{2}$ were obtained by mild heating in the reaction on warm ethanolic solutions of $\mathrm{CuCl}_{2} \cdot 2 \mathrm{H}_{2} \mathrm{O}$ and ligand 4-Bromo-2-(1H-pyrazol-3-yl)phenol in molar ratio 1:2. The formed microcrystals were filtered after $24 \mathrm{~h}$ and washed with ethanol.

Microcrystals of the complex of formula $\mathrm{Zn}(\mathrm{L}-\mathrm{H})_{2}$ were obtained by mild heating in the reaction on warm ethanolic solutions of $\mathrm{Zn}(\mathrm{OAc})_{2} \cdot 2 \mathrm{H}_{2} \mathrm{O}$ and ligand 4-Bromo-2-(1H-pyrazol-3-yl)phenol in molar ratio 1:2. The formed microcrystals were filtered after $24 \mathrm{~h}$ and washed with ethanol. 
Microcrystals of the complex of formula $\mathrm{Ni}(\mathrm{L}-\mathrm{H})_{2} \cdot 4 \mathrm{H}_{2} \mathrm{O}$ were obtained by mild heating in the reaction on warm methanolic solutions of $\mathrm{Ni}(\mathrm{OAc})_{2}$ and ligand 4-Bromo-2-(1H-pyrazol-3-yl)phenol in molar ratio 1:2. The formed microcrystals were filtered after $24 \mathrm{~h}$ and washed with methanol.

Elemental analysis $(\mathrm{C}, \mathrm{H}$ and $\mathrm{N})$ of air-dried compounds was carried out by standard micromethods.

The molar conductivity of freshly prepared $110^{-3} \mathrm{~mol} \mathrm{dm}^{-3}$ solutions of the complexes in DMF was determined at room temperature using a digital conductivity meter Jenway 4510.

These complexes were used to study the inhibition of $P h$. viticola mycelial growth in laboratory conditions. A commercial fungicide which contains pyrazole derivate pyraclostrobin and methiram as active components is used as a standard. Potato dextrose agar (PDA) was prepared as a nutrient medium to test the growth of the fungus. After sterilization of the medium, it was cooled in a water bath at $60{ }^{\circ} \mathrm{C}$ when aqueous solutions of the complexes or a commercial fungicide in certain concentrations were added. For each complex and for a fungicide, five different concentrations were made: $0.12 ; 0.06 ; 0.03 ; 0.015 ; 0.0075(\%) .10 \mathrm{ml}$ of a solution of each chemical complex and a fungicide in certain concentration was added in $100 \mathrm{ml}$ of PDA. After homogenization of the solution of chemicals or fungicide with PDA, the medium was poured into $9 \mathrm{~cm}$ Petri dishes. As a control, the medium with no amendments was used. After agar solidification, mycelial fragments $0.6 \mathrm{~cm}$ in diameter (taken from the edge of 10-day old fungal culture) were placed in the centre of Petri dishes. Inoculated Petri dishes were maintained in incubator at $25{ }^{\circ} \mathrm{C}$. Ten days after the inoculation, mycelial growth of $P h$. viticola was measured (in the control the fungus had covered $2 / 3$ of the Petri dish).

Diameters of fungal mycelium as parameters of the growth inhibition effect were statistically analysed by analysis of variance, and mean values were compared using LSD test. If their difference was greater than the LSD test, they were considered statistically significant (Stankovic et al., 1990). The percentage of fungal inhibition in treatments compared to the control was also calculated for each chemical and for each concentration (Kaiser et al., 2005).

\section{RESULTS AND DISCUSSION}

Results of elemental analysis $(\mathrm{C}, \mathrm{H}$ and $\mathrm{N})$ and molar conductivity is given in Table 1.

Based on the obtained results, it can be concluded that the synthesised complexes and a commercial fungicide have shown statistically significant inhibition of $P h$. viticola in comparison to control. The growth of fungal mycelium $(\mathrm{cm})$ depending on the applied chemical and concentration is given in Table 2.

Average percentage of inhibition achieved by different chemical compounds and certain concentration in comparison to control is presented in Table 3. 
Table 1. Elemental analysis and molar conductivity results for obtained complexes compounds

\begin{tabular}{|l|l|l|l|l|}
\hline $\begin{array}{l}\text { Formulas of the } \\
\text { complex's } \\
\text { compounds }\end{array}$ & $\begin{array}{l}\mathrm{C}(\%) \\
\text { Found ( ) } \\
\text { Calculated }\end{array}$ & $\begin{array}{l}\mathrm{N}(\%) \\
\text { Found } \\
\text { Calculated }\end{array}$ & $\begin{array}{l}\mathrm{H}(\%) \\
\text { Found } \\
\text { Calculated }\end{array}$ & $\begin{array}{l}\lambda_{\mathrm{M}}(\mathrm{DMF}) \\
\mathrm{Scm}^{2} \mathrm{~mol}^{-1}\end{array}$ \\
\hline $\mathrm{Cu}(\mathrm{L}-\mathrm{H})_{2}$ & $\begin{array}{l}39.82) \\
40.06\end{array}$ & $\begin{array}{l}(10.36) \\
10.38\end{array}$ & $\begin{array}{l}(2.33) \\
2.24\end{array}$ & 5.95 \\
\hline$\left[\mathrm{Cu}(\mathrm{L}-\mathrm{H})_{2}\right] \mathrm{Cl}_{2}$ & $(32.70)$ & $(9.11)$ & $(1.95)$ & 33.10 \\
& 33.20 & 8.61 & 1.86 & \\
\hline$[\mathrm{Cu}(\mathrm{L}-$ & $(32.10)$ & $(12.15)$ & $(1.59)$ & 41.00 \\
$\left.\mathrm{H})_{2}\right]\left(\mathrm{NO}_{3}\right)_{2}$ & 32.54 & 12.66 & 1.82 & \\
\hline $\mathrm{Zn}(\mathrm{L}-\mathrm{H})_{2}$ & $(40.02)$ & $(10.42)$ & $(2.40)$ & 3.60 \\
& 39,89 & 10.34 & 2.23 & \\
\hline $\mathrm{Ni}(\mathrm{L}-\mathrm{H})_{2} 4 \mathrm{H}_{2} \mathrm{O}$ & $(35.97)$ & $(8.90)$ & $(2,84)$ & 4.20 \\
& 35.63 & 9.23 & 3.32 & \\
\hline
\end{tabular}

Table 2. The growth of fungal mycelium $(\mathrm{cm})$ depending on the applied chemical and concentration

\begin{tabular}{|c|c|c|c|c|c|c|}
\hline \multirow[b]{2}{*}{$\begin{array}{l}\text { Concentrations } \\
\%\end{array}$} & \multicolumn{5}{|c|}{ Studied compound } & \multirow[b]{2}{*}{ 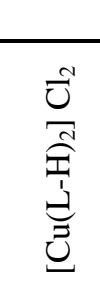 } \\
\hline & $\begin{array}{l}\text { Commercial } \\
\text { fungicide }\end{array}$ & 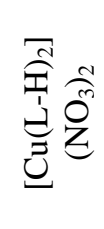 & 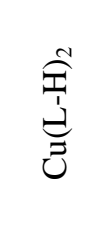 & 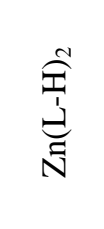 & 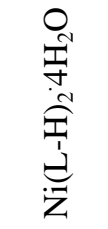 & \\
\hline 0.12 & 0.0 & 5.2 & 5.1 & 3.3 & 3.2 & 1.6 \\
\hline 0.06 & 0.0 & 6.1 & 5.5 & 4.1 & 4.6 & 3.6 \\
\hline 0.03 & 0.0 & 6.6 & 5.8 & 5.4 & 5.2 & 5.2 \\
\hline 0.015 & 1.0 & 6.7 & 6.4 & 5.6 & 5.5 & 5.5 \\
\hline 0.0075 & 1.1 & 6.8 & 6.7 & 6.5 & 5.6 & 6.0 \\
\hline Control & 7.5 & 7.5 & 7.5 & 7.5 & 7.5 & 7.5 \\
\hline$\underline{\mathbf{L S D}}_{0,01}$ & 0.208 & 0.995 & 0.526 & 0.544 & 0.316 & 0.383 \\
\hline
\end{tabular}

Compared to the complex compounds studied, a commercial fungicide expressed the best inhibitory effect. All applied concentrations of a commercial fungicide have shown statistically significant inhibition of $P h$. viticola colony growth in relation to control.

The studied complex compounds had a lower inhibitory effect than a commercial fungicide but with obvious inhibition activity. $\left[\mathrm{Cu}(\mathrm{L}-\mathrm{H})_{2}\right] \mathrm{Cl}_{2}$ complex expressed the best inhibitory effect at concentration of $0.12 \%$.

Concerning $\left[\mathrm{Cu}(\mathrm{L}-\mathrm{H})_{2}\right]\left(\mathrm{NO}_{3}\right)_{2}$ complex, concentrations of 0.12 and $0.06 \%$ exhibited inhibitory activity, while in the other three concentrations used, inhibition was not expressed at the level of a significant statistical difference in regard to control. $\mathrm{Cu}(\mathrm{L}-\mathrm{H})_{2}$ complex showed better inhibitory activity than the 
previous one since all five applied concentrations expressed inhibition effects that were statistically significant compared to control. The best inhibition achieved was at concentration of $0.12 \%$. In relation to similar $\mathrm{Cu}$ (II) complexes examined in previous studies (Jaćimović et al., 2013; Jaćimović et al., 2017a; Jaćimović et al., 2017b), the tested $\mathrm{Cu}$ complexes in this research showed significantly higher inhibition of the growth of $\mathrm{Ph}$. viticola. In previous studies, inhibition in relation to control at the highest concentration of the complexes $(0.12 \%)$ was only $9.3 \%$, $12.1 \%$ and $14.7 \%$.

Table 3. Average $\%$ of inhibition achieved by different chemical compounds and certain concentration in comparison to control

\begin{tabular}{|c|c|c|c|c|c|c|}
\hline \multirow[b]{2}{*}{$\begin{array}{l}\text { Concentrations } \\
\%\end{array}$} & \multicolumn{5}{|c|}{ Studied compound } & \multirow[b]{2}{*}{ 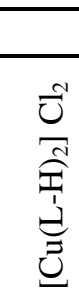 } \\
\hline & $\begin{array}{l}\text { Commercial } \\
\text { fungicide }\end{array}$ & 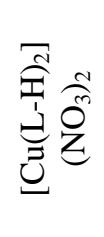 & 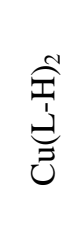 & 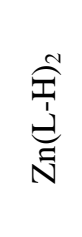 & 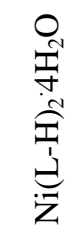 & \\
\hline$\overline{0.12}$ & 100.0 & 30.7 & 32.0 & 56.0 & 57.3 & 78.7 \\
\hline 0.06 & 100.0 & 18.7 & 26.7 & 45.3 & 38.7 & 52.0 \\
\hline 0.03 & 100.0 & 12.0 & 22.7 & 28.0 & 30.7 & 30.7 \\
\hline 0.015 & 86.7 & 10.7 & 14.7 & 25.3 & 26.7 & 26.7 \\
\hline 0.0075 & 85.3 & 9.3 & 10.0 & 13.3 & 25.3 & 20.0 \\
\hline
\end{tabular}

In comparison to $\left[\mathrm{Cu}(\mathrm{L}-\mathrm{H})_{2}\right]\left(\mathrm{NO}_{3}\right)_{2}$ and $\mathrm{Cu}(\mathrm{L}-\mathrm{H})_{2}$ complexes, $\mathrm{Zn}(\mathrm{L}-\mathrm{H})_{2}$ and $\mathrm{Ni}(\mathrm{L}-\mathrm{H})_{2} \cdot 4 \mathrm{H}_{2} \mathrm{O}$ complexes expressed better inhibitory activity. Complex of formula $\mathrm{Zn}(\mathrm{L}-\mathrm{H})_{2}$ caused fungal inhibition growth at all concentrations, which differed statistically from the control, and between each individual concentration, except between the third and the fourth. Maximum inhibition was achieved by the first concentration and it was $56.0 \%$. A similar percentage of inhibition was obtained also in the previous study, where $\mathrm{Zn}$ complex expressed an inhibition of $53.5 \%$ at the highest concentration (Jaćimović et al., 2013). In the testing of $\mathrm{Ni}(\mathrm{L}-\mathrm{H}) 2 \cdot 4 \mathrm{H} 2 \mathrm{O}$ complex, the compound applied in all investigated concentrations expressed significant inhibition compared to control. The best results were obtained at 0.12 and $0.06 \%$ concentrations, while at the other three concentrations applied inhibitory effects were lower and relatively uniform. Compared with the inhibition achieved by the similar $\mathrm{Ni}$ complex previously examined (14.7\%) by Jaćimović et al. (2017b), the percentage of inhibition in this study is almost 4 times higher and amounts to $57.3 \%$.

The complex of formula $\left[\mathrm{Cu}(\mathrm{L}-\mathrm{H})_{2}\right] \mathrm{Cl}_{2}$ achieved the best results from other studied complexes (excluding a commercial fungicide), and especially at concentration of $0.12 \%$ when it inhibited the growth of fungal mycelium at a level of $78.7 \%$, which is the best result in this experiment compared to other synthesised complexes and concentrations and also in comparison to previously reported experiments. 


\section{CONCLUSIONS}

In the reaction on warm alcoholic solution (methanol or ethanol) of metal salts $\mathrm{Cu}(\mathrm{OAc})_{2}, \mathrm{CuCl}_{2}, \mathrm{Cu}\left(\mathrm{NO}_{3}\right)_{2}, \mathrm{Zn}(\mathrm{OAc})_{2}$ and $\mathrm{Ni}(\mathrm{OAc})_{2}$ and 4-Bromo-2-(1Hpyrazol-3-yl)phenol (HL) as ligand in molar ratio 1:2, tree new $\mathrm{Cu}$ (II) complexes, $\mathrm{Zn}(\mathrm{II})$ and $\mathrm{Ni}(\mathrm{II})$ complexes with formulas: $\mathrm{Cu}(\mathrm{L}-\mathrm{H})_{2},\left[\mathrm{Cu}(\mathrm{L}-\mathrm{H})_{2}\right] \mathrm{Cl}_{2},[\mathrm{Cu}(\mathrm{L}-$ $\left.\mathrm{H})_{2}\right]\left(\mathrm{NO}_{3}\right)_{2}, \mathrm{Zn}(\mathrm{L}-\mathrm{H})_{2}$ and $\mathrm{Ni}(\mathrm{L}-\mathrm{H})_{2} 4 \mathrm{H}_{2} \mathrm{O}$ were obtained. Based on elemental analysis $(\mathrm{C}, \mathrm{H}$ and $\mathrm{N})$ and conductivity measurements, formulas of complex compounds were determined.

All complex compounds used in the experiment showed inhibitory activity against the growth of the phytopathogenic fungus Phomopsis viticola, causal agent of Phomopsis cane and leaf spot disease of grapevine. The best inhibition was achieved by the complex $\left[\mathrm{Cu}(\mathrm{L}-\mathrm{H})_{2}\right] \mathrm{Cl}_{2}$ at concentration of $0.12 \%$. At this concentration the inhibition reached $78.7 \%$. These results are of importance for the preparation of the pyrazole compound which will have satisfactory fungicidal activity against $P h$. viticola, since it has shown the best results so far both in this experiment and in previous studies carried out by the same researchers.

\section{ACKNOWLEDGEMENTS}

This research was conducted within the innovation project: „Study on biological efficacy of newly synthesized compounds and plant extract to the most important diseases of grapevine in Montenegro" supported by Ministry of Science of Montenegro.

\section{REFERENCES}

Alex J.M., Kumar R. (2014): 4,5-Dihydro-1H-pyrazole: an indispensable scaffold. Journal of Enzyme Inhibition and Medicinal Chemistry, 29 (3); 427-442.

Chimenti F., Bolasco A., Manna F., Secci D., Chimenti P., Granese A., Befani O., Turini P., Cirilli R., La Torre F., Alcaro S., Ortuso F., Langer T. (2006): Synthesis, biological evaluation and 3D-QSAR of 1,3,5-trisubstituted-4,5-dihydro- $(1 \mathrm{H})$ pyrazole derivatives as potent and highly selective monoamine oxidase A inhibitors. Current Medicinal Chemistry, 13(12); 1411-1428.

Gubler W.D., Nguyen T.T. and Morris S.N. (2015): Fungicide Control of Phomopsis Cane and Leaf Spot on Grapevine: 2015 Field Trial. Published 2015 at: http://plantpathology.ucdavis.edu/Cooperative_Extension/.

Jaćimović Ž., Latinović N., Bošković I., Tomić Z. (2013): The Influence of a Newly Synthesized Zn (II) and Cu (II) Complexes based on Pyrazole Derivatives on the Inhibition of Phomopsis viticola Sacc. (Sacc.) under Laboratory Conditions Research, Journal of Chemistry and Environment, 17(10); 23-27.

Jaćimović Ž., Kosović M., Latinović J., Bigović M., Kastratović V. (2017a): The Influence of Some Pyrazole Derivetes and Newly Synthetised $\mathrm{Cu}$ (II) Complexes to the Inhibition of Phomopsis viticola in vitro. $18^{\text {th }}$ European Meeting on Environmental Chemistry, Porto 26-29 ${ }^{\text {th }}$ November 2017. Book of Abstracts, 320.

Jaćimović Ž.K., Giester G., Kosović M., Bogdanović G.A., Novaković S.B., Leovac V.M., Latinović N., Holl o' B.B., Mészáros Szécsény K. (2017b): Pyrazole-type complexes with $\mathrm{Ni}(\mathrm{II})$ and $\mathrm{Cu}(\mathrm{II})$, Solvent exchange reactions in coordination compounds, Journal of Thermal Analysis and Calorimetry, 127(2); 1501-1509. 
Kaiser C., Van der Merwe R., Bekker T.F. and Labuschagne N. (2005): In-vitro inhibition of mycelial growth of several phytopathogenic fungi, including Phytophthora cinnamomi by soluble silicon. South African Avocado Growers' Association Yearbook 28; 70-74.

Kumar V., Kaur K., Gupta G.K., Sharma A.K. (2013): Pyrazole containing natural products: Synthetic preview and biological significance. European Journal of Medicinal Chemistry, 69; 735-753.

Latinovic N. (2007): Control model of grapevine excoriose in vineyards of Podgorica. $\mathrm{PhD}$ thesis. University of Belgrade, Agricultural Faculty.

Latinovic N., Latinovic J. (2011): The most important mycosis of grapevine in Montenegro. Symposium Power of Fungi and Mycotoxins and Disease. Primošten/Croatia, 19-22 October. Book of Abstracts, 73.

Latinović N., Latinović J., Zindović J. (2003): Sensibility of some varieties of grapevine to causal agent of dead arm disease (Phomopsis viticola Sacc.). Agriculture and Forestry, 49(1-2); 71-77.

Lemaire G, Mnif W, Pascussi JM, Pillon A, Rabenoelina F, Fenet H, Gomez E, Casellas C, Nicolas JC, Cavailles V, Duchesne MJ, Balaguer P. (2006): Identification of new human pregnane $X$ receptor ligands among pesticides using a stable reporter cell system. Toxicological Sciences, 91(2); 501-509.

Pscheidt J.W., Pearson R.C. (1989): Time of Infection and Control of Phomopsis Fruit Rot of Grape. Plant Disease, 73(10); 829-833.

Singh N., Sangwan N.K., Dhindsa K.S. (2000): Synthesis and fungitoxic activity of 5aryl-1 formyl-4,5-dihydro-3-(2-hydroxyphenyl)-1Hpyrazoles and their complexes. Pest Management Science. 56(3); 284-288.

Stankovic J., Lakic N., Ljubanovic-Ralevic I. (1990): Exercises in experimental statistics. University of Belgrade, Faculty of Agriculture, p. 242 (in Serbian).

Statistical yearbook (2017): Published by: Statistical Office of Montenegro - MONSTAT.

Trofimenko S. (1986): Progress in Inorganic Chemistry, Wiley-Interscience, New York, $34 ; 115$.

Vicentini C.B., Mares D., Tartari A., Manfrini M., Forlani G. (2004): Synthesis of pyrazole derivatives and their evaluation as photosynthetic electron transport inhibitors. Journal of Agricultural and Food Chemistry, 52(7); 1898-906. 